\title{
AN INVESTIGATION ONTHE EFFECT OF MOISTURE CONTENT, CROP DIAMETER AND CUTTING SPEED ON CUTTING \\ FORCE OF FINGER MILLET STEM
}

\author{
N. NISHA ${ }^{1} \&$ M. SARAVANAKUMAR ${ }^{2}$ \\ ${ }^{I}$ Research Scholar, Agricultural Engineering College and Research Institute, Kumulur, Tamil Nadu, India \\ ${ }^{2}$ Associate Professor (FMP), Department of Farm Machinery \& Power Engineering, Agricultural \\ Engineering College and Research Institute, Kumulur, Tamil Nadu, India
}

Cutting force was one of the important parameter for optimized design of harvesting machines. The effect of moisture content, crop diameter and cutting speed on cutting force and cutting energy for finger millet were investigated using a cutter bar test rig. Experiments were carried out on a high yielding ruling variety $\mathrm{CO}(\mathrm{Ra}) 14$ at four levels of cutter bar speed $\left(1.0,1.25,1.5,2.0 \mathrm{~ms}^{-1}\right)$, three levels of stem diameter $(6,9$ and $12 \mathrm{~mm})$ and three levels of moisture content (62 to 63, 70 to 71 , and 77 to 80 percent). It was observed that with increase in moisture content from 62 to 80 per cent, cutting force and energy decreased by 16.2 per cent. With increase in stem diameter from 6 to 12 mm, cutting force and energy increased by 7.3 percent. The cutting force $(190.63 \mathrm{~N})$ and energy $(1.14 \mathrm{~J})$ was minimum at the cutting speed of $2 \mathrm{~ms}^{-1}$ for $6 \mathrm{~mm}$ stem diameter at 78 per cent moisture content and they were maximum at a cutting speed of 0.5 $\mathrm{ms}^{-1}$ (370.97 $\mathrm{N}$ and 4.45J)for $12 \mathrm{~mm}$ stem diameter respectively.

KEYWORDS: Finger Millet, Harvesting, Cutting Force \& Cutting Energy
\end{abstract}

Received: Mar 19, 2019; Accepted: Apr 11, 2019; Published: May 09, 2019; Paper Id.: IJASRJUN201929

\section{INTRODUCTION}

Finger millet is grown in more than 25 countries of African and Asian continents. Uganda, India, Nepal, and China are the major ragi producers of the world. In India, it is extensively grown in Karnataka, Tamil Nadu, Andhra Pradesh, Orissa, Bihar, Gujarat and Maharashtra and the hilly regions of Uttar Pradesh and Himachal Pradesh. Karnataka is the leading producer of ragi with 53.94 per cent of the total area and 53.36 per cent of the total production of the crop in the country. Tamil Nadu occupies second place in respect of area (7.52\%) and production (14.60\%) of ragi in India. The chief producers are Coimbatore, Dharmapuri, Ramanathapuram, Salem, North and South Arcot, Nilgiris, Chengalpet and Madurai districts. The high yielding improved varieties of finger millet cultivated in India are CO-9, CO-13, CO (Ra)-14, TRY-1, Paiyur-1, Paiyur-2, VL Mandua-101, 124, 149, 204, 146, 314, 315, H-22, K-1, Hullubele, Karegidda, Gidda, Jasarilambi, Madayyanagiri-1,2, Dodda, Jadesange, Jenumudda.

Traditionally, finger millet is harvested manually in two methods. In one method, earheads are first harvested manually with sickles and then the straw is cut to the ground level. Earheads are heaped under sunlight for 3 to 4 days to cure and then threshed. In the second method, the whole plant along with the earhead is reaped and subjected to threshing. The second method is predominent under rain-fed condition. For mechanized harvesting of finger millet, the data regarding the structural properties of the finger millet stalk is important. 
Majumdar and Dutta (1982) reported that increasing the cutting speed resulted in decreased cutting force and consequently the shear energy. Chattopadhyay and Pandey (1999) concluded that the knife bevel angle did not appear to have any significant effect on total specific energy requirement. Yiljep and Mohammed (2005) reported that cutting energy had negative linear correlation with knife velocity and stalk moisture content. Dange et al., (2012) observed that cutting energy and force decreased with increase in moisture content. The commercially available harvesting units have cutting blade of width $76.2 \mathrm{~mm}$. The cutter bar of $76.2 \mathrm{~mm}$ stroke length is in used to cut grasses, cereals and commercial crops of thin stalk(Das, 1998). The investigation was carried out for Co (Ra) 14 variety of finger millet with the following objectives

- To identify the pertinent crop and machine parameters that influences the harvesting of finger millet

- To investigate the influence of crop and machine parameters on cutting force and energy required for harvesting of finger millet.

\section{MATERIALS AND METHODS}

The pertinent parameters influencing the harvesting of crop were identified as moisture content, stem diameter and linear speed of the cutter bar.

\section{Crop Parameter}

\section{- Moisture Content}

Three levels of moisture contents were selected based on the observation made at ten days before harvest (77 to 80 per cent), at the time of harvest (70 to 71 per cent), and ten days after the harvesting period (62 to 63 per cent). Moisture content was determined using the formula given below

$$
\text { Moisture content }(\mathrm{d} . \mathrm{b})=\frac{W_{w}-W_{d}}{W_{d}} \times 100, \text { percent }
$$

Where,

$\mathrm{W}_{\mathrm{w}}=$ Weight of the sample of finger millet stem before drying, $\mathrm{g}$

$\mathrm{w}_{\mathrm{d}}=$ Weight of the dried finger millet stem, $\mathrm{g}$

\section{- Stem Diameter}

The stem diameter is defined as the diameter of the plant measured at desired height (height at which actual harvesting to be done) above ground level. Fifteen random samples of finger millet stem at optimum harvesting stage were selected from field and the diameter of the stalk was measured using vernier caliper and recorded. The mean value of 6 $\mathrm{mm}, 9 \mathrm{~mm}, 12 \mathrm{~mm}$ was calculated and used for the investigation.

\section{Machine Parameter}

\section{- Linear Speed of Cutter Bar}

The linear speed of cutter bar was calculated using the following equation (Celik, 2006)

$$
\mathbf{V}_{\mathbf{k}}=\frac{\mathbf{S} \times \mathbf{n}}{30}
$$


Where,

$$
\begin{aligned}
& \mathrm{V}_{\mathrm{k}}=\text { Knife speed, } \mathrm{ms}^{-1} \\
& \mathrm{~S}=\text { Length of stroke, } \mathrm{m} \\
& \mathrm{n}=\text { Crank speed, } \mathrm{rpm}
\end{aligned}
$$

Four cutter bar speeds were selected for the study based on the cutting speed selected by earlier researchers are $0.5,1,1.5$ and $2 \mathrm{~ms}^{-1}$.

\section{Evaluation Parameter}

\section{- Cutting Force}

Cutting force is the maximum force required for cutting the finger millet crop. The cutting force measured using the load cell is indicated in kilogram on the load indicator. The cutting force for every stem was recorded and used for analysis

\section{- Cutting Energy}

The cutting energy was calculated from the cutting force using the formula

$$
E_{C}=F_{C} \times D
$$

Where,

$$
\begin{aligned}
& E_{C}=\text { Cutting energy }, \mathrm{J} \\
& F_{C}=\text { Cutting force, } \mathrm{N} \\
& \mathrm{D}=\text { Diameter } \mathrm{m}
\end{aligned}
$$

\section{Test Rig}

Cutting force was measured using a reciprocating cutter bar test rig which consists of a motor, power transmission system, cutter bar assembly, load cell and load indicator (Figure 1). The S-type load cell was used to measure the cutting force. The load cell was placedon the connecting rod between the cutter bar and crank. The finger millet stem was fed between the reciprocating cutter bar blades and stationary ledger plates of the cutter bar test rig and, with the dynamic actuation of the blades; the stem was cut into two pieces. The peak cutting force exerted by cutter bar was sensed by the strain gauges in the load cell and thevalues were indicated in $\mathrm{kg}$ in the load indicator.

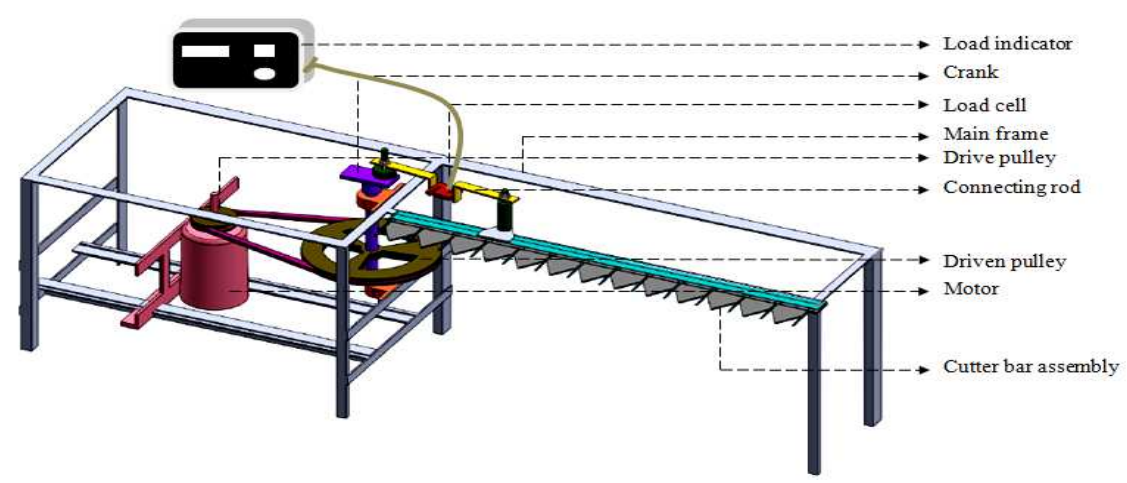

Figure 1: Cutter Bar Test Rig 


\section{OPERATIONAL PARAMETERS}

Experiments were carried out at four levels of cutter bar speeds 1, 1.25, 1.5, 2.0 ms ${ }^{-1}$ three levels of crop diameter $6 \mathrm{~mm}, 9 \mathrm{~mm}, 12 \mathrm{~mm}$ and three levels of moisture content 62.3 to $63.25,69.6$ to 70.6 , and 76.67 to 80 percent. The response parameters measured during the experiment was cutting force.

\section{RESULTS AND DISCUSSIONS}

The effect of peak cutting force and energy on cutter bar speed, stem diameter and moisture content were studied and the results were discussed below.

\section{Effect of Cutter Bar Speed on Peak Cutting Force and Cutting Energy of Ragi Crop Stalk}

It was observed that the increase in the cutting speed decreased the cutting force and energy. The maximum cutting force and energy was found at $0.5 \mathrm{~ms}^{-1}$, due to the influence of less impact force. The maximum cutting force observed was $334.68 \mathrm{~N}$ and $370.97 \mathrm{~N}$ for $6 \mathrm{~mm}$ and $12 \mathrm{~mm}$ stem diameter, respectively. The minimum cutting force and energy observed at $2 \mathrm{~ms}^{-1}$. The minimum cutting force observed at cutter bar speed was $223.21 \mathrm{~N}$ and $243.07 \mathrm{~N}$ for $6 \mathrm{~mm}$ and $12 \mathrm{~mm}$ stem diameter respectively. The minimum value of cutting energy was calculated as $1.34 \mathrm{~J}$ and $2.92 \mathrm{~J}$ for $6 \mathrm{~mm}$ and $12 \mathrm{~mm}$ stem diameter respectively at $2 \mathrm{~ms}^{-1}$. The effect of cutter bar speed on cutting force and energy is shown in Figure 2. There is an inverse relationship between both cutting speed and cutting force.
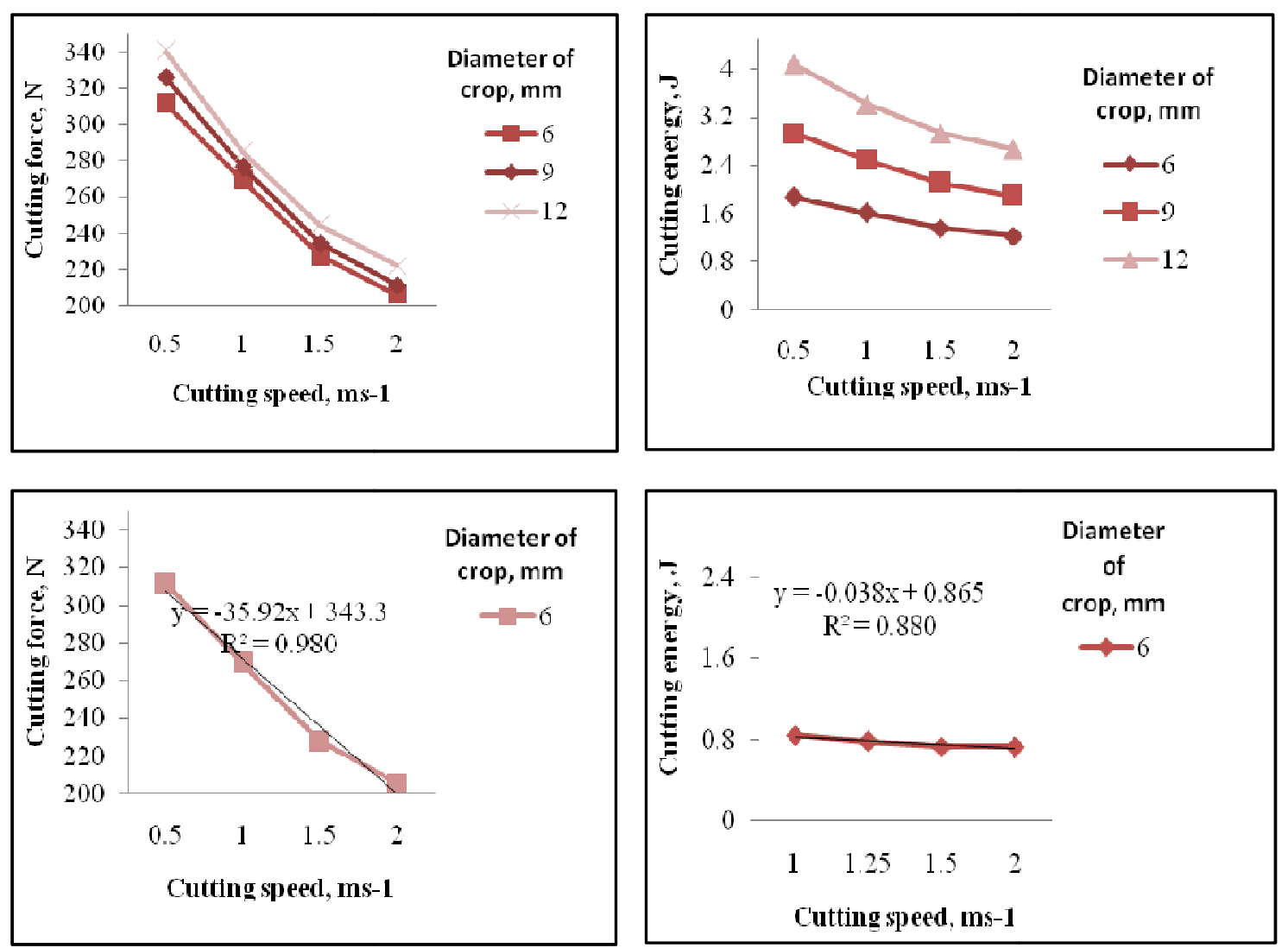

Figure 2: The Effect of Cutter Bar Speed on Cutting Force and Energy

Effect of Moisture Content on Peak Cutting Force and Cutting Energy of Ragi Crop Stalk

It was observed that increase in moisture content decreased the cutting force and energy. The maximum cutting 
force and energy $(370.977 \mathrm{~N}$ and $4.45 \mathrm{~J})$ was found at 63.25 per cent moisture content for the stem diameter of $12 \mathrm{~mm}$. The minimum cutting force and energy $(204.04 \mathrm{~N})$ and $(2.45 \mathrm{~J})$ was recorded at 78 per cent for a stem diameter of $12 \mathrm{~mm}$. The effect of moisture content on cutting force and energy is shown in Figure 3. An inverse relation was observed between moisture content and cutting force.
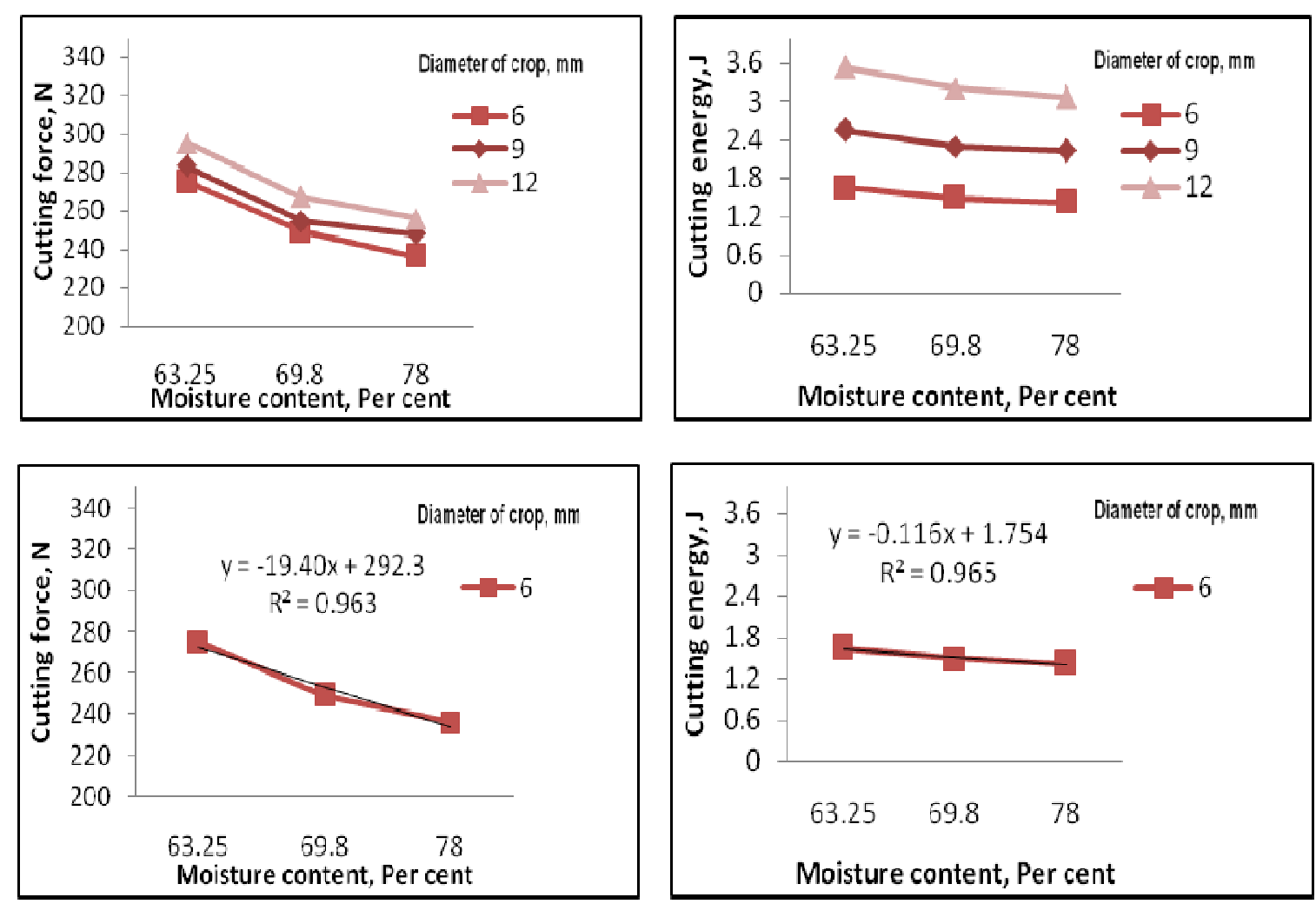

Figure 3: The Effect of Moisture Content on Cutting Force and Energy

\section{Effect of Stem Diameter on Peak Cutting Force and Cutting Energy of Ragi Crop Stalk}

The cutting force and energy increased with stem diameter due to the increase in cutting area. The maximum and minimum cutting force observed was of $370.977 \mathrm{~N}$ and $334.68 \mathrm{Nat} 0.5 \mathrm{~ms}^{-1}$ cutting speed at 63.25 per cent moisture content for $12 \mathrm{~mm}$ and $6 \mathrm{~mm}$ stem diameter. The cutting energy wascalculated as $4.32 \mathrm{~J}$ for $12 \mathrm{~mm}$ stem diameter and $2.01 \mathrm{~J}$ for 6 $\mathrm{mm}$ stem diameter. From the graph a positive correlation between the cutting force and energy could be observed and eventuallyincreasing stem diameter increases the cutting force and energy.
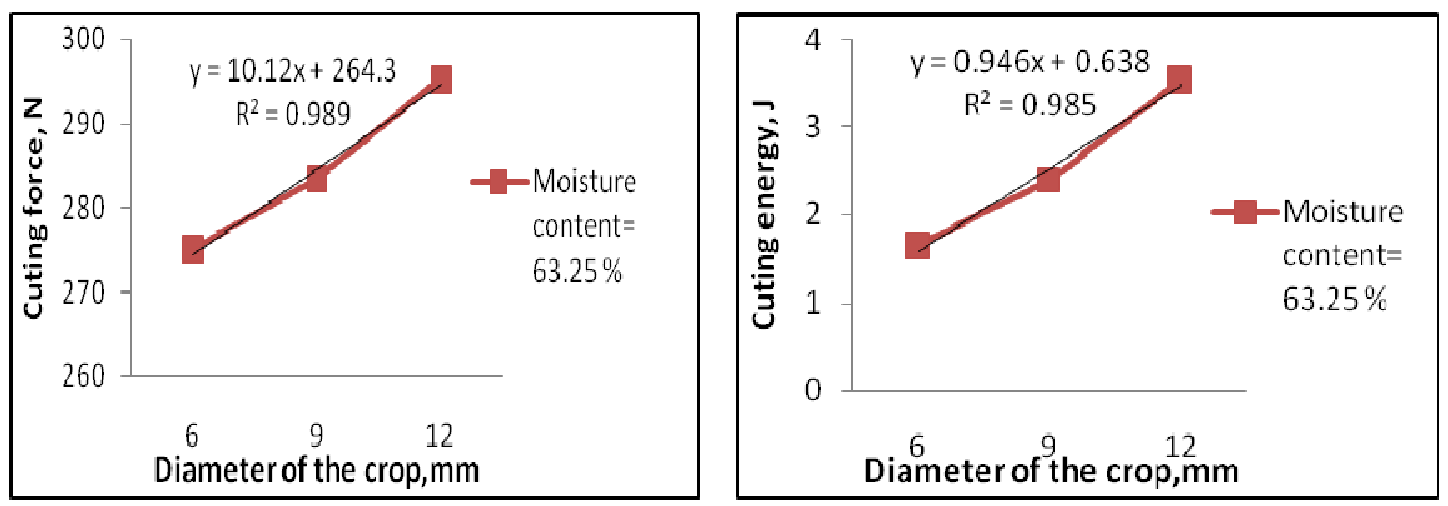

Figure 4: The Effect of Stem Diameter on Cutting Force and Energy 


\section{CONCLUSIONS}

From the cutting force measured the power requirement for designing harvesters for finger millet was calculated. It was observed that the cutting speed and moisture content shows negative correlation with cutting force and energy. The stem diameter showed a positive correlation with both cutting force and energy. It was concluded that at $2 \mathrm{~ms}^{-1}$, the force required for cutting finger millet was minimum.

\section{REFERENCES}

1. Majumdar, M and R. K. Dutta(1982). Impact cutting energy of paddy and wheat by a pendulum type dynamic test. Journal of Agricultural Engineering Research, 19(4): 258-264.

2. Das, P. K. (1998). Design of cutter bar. Design, testing and production technology of harvesting and threshing equipment. L7: $1-20$

3. Chattopadhyay, P. S and K. P. Pandey. (1999). Effect of Knife and Operational Parameters on Energy Requirement in Flail Forage Harvesting. Journal of Agricultural Engineering Research. 73:3-12.

4. Yiljep, Y. D and U.S. Mohammed. (2005). Effect of Knife Velocity on Cutting Energy and Efficiency during Impact Cutting of Sorghum Stalk. Agricultural Engineering International: the CIGR E-Journal, 7: 1-10.

5. Alou, I. N., van Asten, P. J., \& Tenywa, M. M. (2014). Biophysical and Crop Management Gradients Limiting Yields of East African Highland Banana (Musa spp. aaa-ea) within Farms in Low Input Cropping Systems. International Journal of Agricultural Science and Research (IJASR), 4(3), 27-43.

6. Dange, A.R., S.K.Thakare, I.Bhaskarrao and U.Momin. (2012). Design of front mounted pigeon pea stem cutter. Journal of agricultural technology, 8 (2):417-433. 